\title{
Novobiocin and the differentiation of peptococci and peptostreptococci
}

\author{
M. W. D. WREN, C. P. ELDON, AND G. H. DAKIN \\ From the Microbiology Department, North Middlesex Hospital, London
}

SUMMARY Paper discs containing $5 \mu \mathrm{g}$ of novobiocin were used as a presumptive test to differentiate $\frac{\mathrm{\Omega}}{\mathrm{O}}$ peptococci and peptostreptococci. Zone diameters were measured and minimum inhibitory con- $\dot{\omega}$

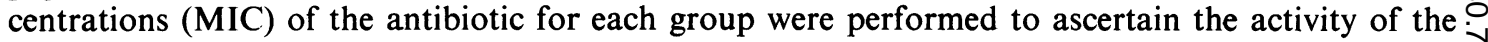
antibiotic against these genera. All strains of peptococci showed no zone of inhibition in the disc ${ }^{\circ}$ test together with an MIC of $25 \mu \mathrm{g} / \mathrm{ml}$ or greater. All strains of peptostreptococci showed zones of 0 inhibition of at least $15 \mathrm{~mm}$ diameter together with an MIC of $1.6 \mu \mathrm{g} / \mathrm{ml}$ or less.

Novobiocin has been used as a method for differentiating micrococci and staphylococci by their resistance or sensitivity respectively (Mitchell and Baird-Parker, 1967). Since such differentiating properties are associated with this antibiotic it seemed of interest to investigate this property with other groups of cocci. The anaerobic Gram-positive cocci are such a mixed group in which a preliminary test would be helpful to differentiate the members in that group.

\section{Material and method}

A series of anaerobic Gram-positive cocci isolated from clinical specimens were tested. Our methods for the culture of clinical specimens and the isolation of anaerobic bacteria from them has been published previously (Wren et al., 1977).

CONFIRMATION OF ANAEROBIC COCCI

Colonies of anaerobic cocci were purified by being plated on two plates of brucella agar (Difco Laboratories, West Molesey, Surrey) supplemented with $5 \%$ horse blood and $0.5 \mu \mathrm{g} / \mathrm{ml}$ menadione (Sigma Chemical Co, Kingston-upon-Thames, Surrey). One plate was incubated anaerobically in stainless steel anaerobic jars (Stuart Scientific Co, Croydon, Surrey) containing an atmosphere of $90 \%$ hydrogen and $10 \%$ carbon dioxide and processed by the method of Watt and Collee (1974). The second plate was incubated in an atmosphere of air plus $10 \%$ carbon dioxide. Incubation times for these plates

Received for publication 17 January 1977 were generally five days at $37^{\circ} \mathrm{C}$. Gram-positive $\vec{\overrightarrow{ }}$ cocci growing only on the anaerobic plates were further tested.

IDENTIFICATION OF ANAEROBIC COCCI A colony of the isolate taken from the pure culture $\bar{O}$ on brucella blood agar was inoculated into $50 \mathrm{ml}$ of Brewer's thioglycollate (Southern Group Labor- \& atories, Lewisham, London) supplemented with $5 \mu \mathrm{g} / \overrightarrow{\vec{\sigma}}$ $\mathrm{ml}$ haemin (BDH Ltd, Poole, Dorset), $0.5 \mu \mathrm{g} / \mathrm{ml} \frac{}{3}$ menadione (Sigma Chemical Co Ltd), $1 \mathrm{mg} / \mathrm{ml} \underset{ }{\supset}$ sodium bicarbonate (Hopkins and Williams, Romford, Essex), and $0.1 \%(\mathrm{v} / \mathrm{v})$ Tween 80 (Sigma Chemical Co Ltd).

This Thio culture was incubated at $37^{\circ} \mathrm{C}$ in an $\frac{{ }^{\circ}}{3}$ ordinary incubator. When good growth was obtained (generally overnight or for 48 hours) the following biochemical tests were inoculated. Approximately $2 \mathrm{ml}$ of Thio culture was added to $0.2 \mathrm{ml}$ of sterile $5 \%$ Tween 80 in a tube and 5 drops of this suspension $\frac{7}{2}$ was added to $5 \mathrm{ml}$ of peptone yeast extract broth containing the following sugars: cellobiose, fructose, $N$ glucose, lactose, maltose, melezitose, and sucrose at $1 \%$, and aesculin at $0.5 \%$. Five drops of the Thio suspension were also added to $5 \mathrm{ml}$ of indole-nitrate $\omega$ broth (Becton-Dickinson, Wembley, Middlesex) and to $5 \mathrm{ml}$ of peptone yeast extract glucose broth too which had been added a charcoal gelatin disc (Oxoid $\mathbb{D}$ Ltd, Basingstoke, Hants) to detect gelatin lique- $\stackrel{?}{+}$ faction. All biochemical media were incubated ${ }_{T}$ anaerobically for five days at $37^{\circ} \mathrm{C}$. The basal $\frac{O}{\mathbb{Q}}$ medium for these tests and the sugar concentrations were as published by Holdeman and Moore (1972). \& Tests were developed and read according to these workers. 
The cellular morphology of each isolate was examined by the following methods: (1) Phasecontrast microscopy of a peptone yeast extract glucose culture using a Watson Hilux 70 microscope with Phase 70 fittings (MEL Equipment Co Ltd, Watson Microscope Division, Barnet, Herts); (2) Gram stains of plate and broth cultures of each isolate.

Identification and nomenclature was performed using the Anaerobe Laboratory Manual of Holdeman and Moore (1972). We grouped together Peptococcus magnus and Peptococcus prevotii because gas liquid chromatography was not available to separate these two species at the time of this study.

\section{NOVOBIOCIN DISC TESTS}

Three drops from a Pasteur pipette of the pure Thio culture were spread over the surface of a brucella blood agar plate and two discs of novobiocin $5 \mu \mathrm{g}$ (Oxoid Ltd) were pressed firmly onto the surface of the agar $45 \mathrm{~mm}$ apart. Plates were incubated anaerobically for 48 hours before being read. Zone diameters were read and recorded.

The effects of anaerobiosis on novobiocin activity were checked by performing sensitivity tests against the Oxford staphylococcus both aerobically and anaerobically. Neither potentiation nor depression of novobiocin activity was noted.

\section{NOVOBIOCIN MIC}

Doubling dilutions of novobiocin (Upjohn Co Ltd, Crawley, Sussex) from $25 \mu \mathrm{g} / \mathrm{ml}$ to $0 \cdot 19 \mu \mathrm{g} / \mathrm{ml}$ were made in brucella broth (Difco Laboratories Ltd) supplemented with haemin $5 \mu \mathrm{g} / \mathrm{ml}$. The inoculum used was $0.02 \mathrm{ml}$ of a $1 / 10$ dilution in brucella broth of an overnight Thio culture. This inoculum was added to $1 \mathrm{ml}$ aliquots of the novobiocin (adding approximately $10^{7}$ colony-forming units to each tube). Control tubes consisted of broth only, broth plus organism, and broth plus antibiotic. All tubes were incubated anaerobically at $37^{\circ} \mathrm{C}$ for 72 hours before being read. Reading from the lowest concentration of antibiotic, the MIC was taken as the first tube to show no growth.

\section{Results}

The identification and antibiotic studies were performed separately and compared only after both had been completed.

\section{IDENTIFICATION}

A total of 63 strains were identified, and Table 1 lists the number of each species identified. A total of 39 peptococci and 24 peptostreptococci were examined.
Table 1 Results of novobiocin disc tests

\begin{tabular}{lrll}
\hline Organism & \multirow{2}{*}{$\begin{array}{l}\text { No. } \\
\text { tested }\end{array}$} & \multicolumn{2}{l}{$5 \mu \mathrm{g}$ disc of novobiocin } \\
\cline { 3 - 4 } & & No. sensitive & No. resistant \\
\hline Peptostreptococcus & 19 & 19 & 0 \\
$\quad$ anaerobius & 2 & 2 & 0 \\
micros & 1 & 1 & 0 \\
productus & 2 & 2 & 0 \\
parvulus & 16 & 0 & 16 \\
Peptococcus & 22 & 0 & 22 \\
asaccharolyticus & 1 & 0 & 1 \\
magnus/prevotii & & & \\
saccharolyticus & &
\end{tabular}

\section{DISC TESTS}

When tested against a disc of novobiocin $(5 \mu \mathrm{g})$ all strains of peptococci grew up to the margins of the discs, showing no zone of inhibition.

All peptostreptococci had a zone of inhibition of at least $15 \mathrm{~mm}$ and often greater (Table 1).

\section{RESULTS OF MIC TESTS}

The MIC results show a greater difference between the two genera. Table 2 summarises the findings when MICs were tested by tube dilution. All peptococci had an MIC of at least $25 \mu \mathrm{g} / \mathrm{ml}$.

The MIC of peptostreptococci extended over four tubes and ranged between 1.56 and $0.39 \mu \mathrm{g} / \mathrm{ml}$.

\section{Discussion}

Antibiotic susceptibility patterns for the differentiation of anaerobic bacteria have been used with success by some workers (Sutter and Finegold, 1971) and form part of a group of well-established primary identification tests (Sutter et al., 1975). The use of such tests provides the clinical laboratory with simple and convenient methods for the presumptive identification of common anaerobes found in clinical specimens.

Novobiocin has been used successfully in this way with micrococci and staphylococci (Mitchell and Baird-Parker, 1967) and has even aided in the recognition of clinically important types (Alder et al., 1966). Since novobiocin possesses these differentiating properties it was decided to test a series of anaerobic Gram-positive cocci against this antibiotic both by disc sensitivity test and by the performance of minimum inhibitory concentrations in broth by tube dilution.

The results show that a differentiation between peptococci and peptostreptococci may be achieved, but it must be remembered that the majority of peptostreptococci were Pst. anaerobius (the peptostreptococcus found most frequently in clinical material) and that the majority of peptococci were 
Table 2 Results of MIC tests

\begin{tabular}{|c|c|c|c|c|c|c|c|c|c|c|}
\hline \multirow[t]{2}{*}{ Organism } & \multirow[t]{2}{*}{ No. tested } & \multicolumn{9}{|c|}{ No. of strains inhibited by novobiocin at $(\mu \mathrm{g} / \mathrm{ml})$ : } \\
\hline & & $>25$ & 25 & $12 \cdot 5$ & $6 \cdot 25$ & $3 \cdot 12$ & $1 \cdot 56$ & $0 \cdot 78$ & $0 \cdot 39$ & $0 \cdot 19$ \\
\hline $\begin{array}{l}\text { Peptostreptococcus anaerobius } \\
\qquad \begin{array}{l}\text { micros } \\
\text { productus } \\
\text { parvulus }\end{array}\end{array}$ & $\begin{array}{r}19 \\
2 \\
1 \\
2\end{array}$ & & & & & & 10 & $\begin{array}{l}6 \\
1\end{array}$ & $\begin{array}{l}3 \\
1 \\
1 \\
2\end{array}$ & \\
\hline $\begin{array}{r}\text { Peptococcus asaccharolyticus } \\
\text { magnus/prevotii } \\
\text { saccharolyticus }\end{array}$ & $\begin{array}{r}16 \\
22 \\
1\end{array}$ & $\begin{array}{l}11 \\
16\end{array}$ & $\begin{array}{l}5 \\
6 \\
1\end{array}$ & & & & & & & \\
\hline
\end{tabular}

Pc. asaccharolyticus and magnus/prevotii, so that our results reflect heavily on these species.

Guillermot and his colleagues (1966) tested 74 members of the Micrococcaceae and found irregular results when testing the susceptibility of these organisms to novobiocin but did not give the identity of the strains that were sensitive or resistant.

In the present study, both disc tests and minimum inhibitory concentrations show that novobiocin resistance may be a characteristic associated with the peptococcus, and we conclude that this antibiotic may prove to be useful in the primary differentiation of peptococciand peptostreptococci in the laboratory.

We should like to thank Upjohn Co. Ltd for the supply of novobiocin powder for the MIC determinations.

\section{References}

Alder, V. G., Brown, A. M., and Mitchell, R. G. (1966). The tellurite reactions of coagulase negative staphylococci and micrococci. Journal of Applied Bacteriology, 29, 304-307.

Guillermot, F. N., Courtieu, A. L., Longeray, C., Rabut, A. M., and Moinecourt, N. (1966). Etude sur la sensibilité aux antibiotiques de 164 asporulales et 50 Actinomycétales anaérobies. Annales de l'Institut Pasteur, 111, 503-512.

Holdeman, L. V. and Moore, W. E. C. (eds.) (1972). Anaerobic Laboratory Manual. Virginia Polytechnic Institute and State University, Blacksburg, Virginia, USA.

Mitchell, R. G. and Baird-Parker, A. C. (1967). Novobiocin resistance and the classification of staphylococci and micrococci. Journal of Applied Bacteriology, 30, 251-254.

Sutter, V. L. and Finegold, S. M. (1971). Antibiotic disc . susceptibility tests for rapid presumptive identification of gram-negative anaerobic bacilli. Applied Microbiology, 21, 13-20.

Sutter, V. L., Vargo, V. L., and Finegold, S. M. (1975). Wadsworth Anaerobic Bacteriology Manual, 2nd edition. Department of Continuing Education in Health Sciences, University Extension, and the School of Medicine, UCLA, Los Angeles, USA.

Watt, B. and Collee, J. G. (1974). Practical approaches to the isolation and identification of clinically important non-sporing anaerobes. In Infection with NonSporing Anaerobic Bacteria, edited by I. Phillips and M. Sussman, pp. 7-19. Churchill Livingstone, Edinburgh.

Wren, M. W. D., Baldwin, A. W. F., Eldon, C. P., and Sanderson, P. J. (1977). The culture of clinical specimens $₹$ for anaerobic bacteria -a 14 month study. Journal of $\mathrm{O}$ Medical Microbiology, 10, 49-61. 